\title{
THE MOSS ACTINODONTIUM ADSCENDENS - NEW TO INDIA FROM THE WESTERN GHATS
}

\author{
R. SReebha and A. E. D. Daniels* \\ Bryology Laboratory, Department of Botany and Research Centre, Scott Christian College \\ Nagercoil-629 003, Tamil Nadu, India; *E-mail: dulipdaniels@yahoo.co.uk
}

(Received 27 December, 2016; Accepted 17 April, 2017)

The moss Actinodontium adscendens is added here to the flora of India from the Western Ghats of Peninsular India. It is described and illustrated with notes on its habitat.

Key words: Actinodontium adscendens, Anamalais, Western Ghats

\section{INTRODUCTION}

Actinodontium Schwägr. appears to be rare in India with only one species, namely Actinodontium rhaphidostegum (Müll. Hal.) Bosch et Sande Lac. (Bruehl 1931, Chopra 1975, Gangulee 1969-1980, Lal 2005, Schwarz 2013). While studying the bryoflora of the Indira Gandhi National Park, Anamalais in the Western Ghats, another species of Actinodontium was collected, which was later assigned to Actinodontium adscendens Schwägr. This discovery is a new record for India and adds one more indigene to this genus. A brief description substantiated with illustrations and notes on its habitat are provided.

Actinodontium adscendens Schwägr. can be readily distinguished from $A$. rhaphidostegum (Müll. Hal.) Bosch et Sande Lac. as follows:

1a Leaves ovate to oblong-ovate, flat to slightly recurved below, acute to short-acuminate at apex; costa $3 / 4$ as long as leaf

A. adscendens

$1 b$ Leaves oblong-lanceolate, distinctly recurved for $2 / 3$ below, gradually acuminate at apex; costa $4 / 5$ as long as leaf

A. rhaphidostegum 
Actinodontium adscendens Schwägr.,

Sp. Musc. Frond., Suppl. 2(2): 75 (1826)

(Figs 1-6)

Bruehl, Rec. Bot. Surv. India 13(1): 82 (1931); Mohamed et Robinson, Smiths. Contr. Bot. 80: 4 (1991) (as A. ascendens). - Type: Indonesia (Java), sine loco, Reinwardt s.n. (G?).

Plants caespitose, $4-7 \mathrm{~mm}$ tall, yellow-green to green. Stems simple, $0.28-0.32 \times 0.18-0.24 \mathrm{~mm}$ in cross section, ovate, without a central strand; cortex 1- or 2-layered; cells 8-10 $\times 4-8 \mu \mathrm{m}$, quadrate to rounded-quadrate, thick-walled; medullary ones $6-12 \times 4-10 \mu \mathrm{m}$, rounded-quadrate to roundedhexagonal, thin-walled. Leaves crowded, erect, slightly shrunken or crisped when dry, $1.8-2.2 \times 0.4-0.7 \mathrm{~mm}$, ovate to oblong-ovate, entire above, flat to slightly recurved below, acute to short-acuminate at apex; cells thin-walled, rhomboid to elongate-hexagonal; apical and median cells 40-120 × 16-20 $\mu \mathrm{m}$; basal ones 30-100 × 12-16 $\mu \mathrm{m}$, elongate-hexagonal to linear; costa ca $3 / 4$ as long as leaf, unequal, parallel. Sporophyte not seen.

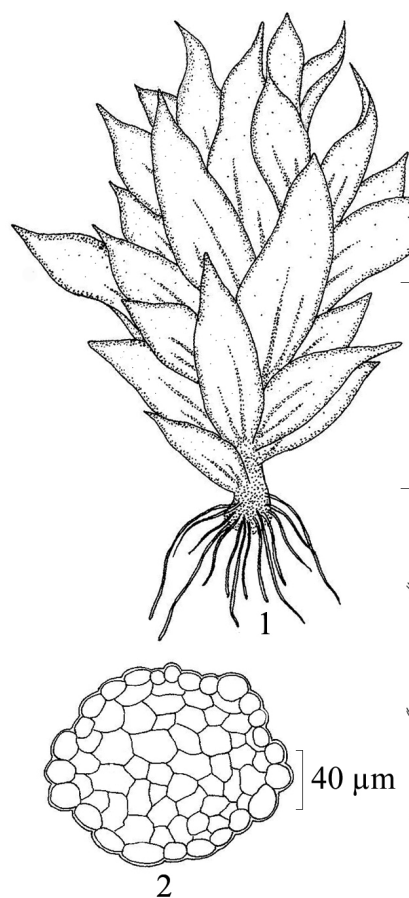

2

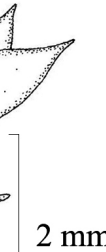

$2 \mathrm{~mm}$

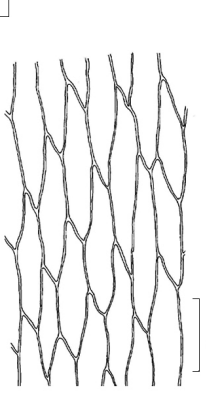

5

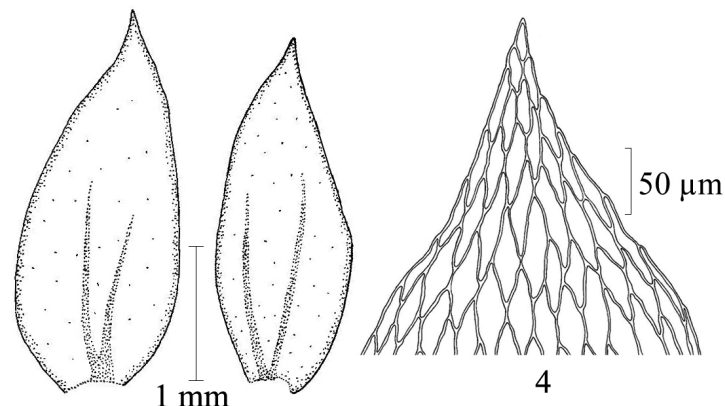

3

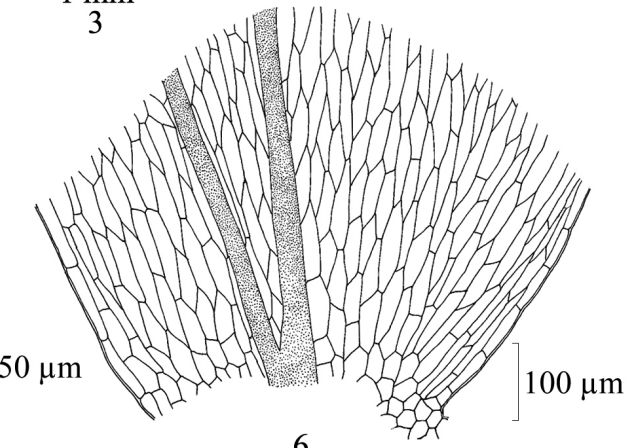

6

Fig. 1. Actinodontium adscendens Schwägr. $-1=$ plant; $2=$ cross section of stem; $3=$ leaves; $4=$ leaf apical cells; 5 = leaf median cells; $6=$ leaf basal cells (drawn from Daniels, A. E. D., 8623 p.p.) 
Habitat: Corticolous on Camellia sinensis (L.) O. Kuntze (Theaceae), in tea plantations, ca $960 \mathrm{~m}$.

Distribution: Indonesia (Java), Malaya, the Philippines, Sri Lanka, Thailand and India: Western Ghats of Tamil Nadu (Coimbatore).

Specimen examined: Western Ghats: Tamil Nadu, Coimbatore Dist., Anamalais, Valparai, Anali estate. Alt.: ca 960 m a.s.l. Coll.: Daniels, A. E. D. (8623 p.p.), 11.8.2012 (SCCN).

\section{DISCUSSION}

In the present survey, Actinodontium adscendens was found to grow on tea plants in the plantations of Anali estate. It is interesting to note that one of the earlier collections was also from a tea plantation in Cameron (Mohamed and Robinson 1991). The species has also been reported from Sri Lanka where tea plantations are not uncommon. Moreover, Western Ghats, especially the southern part and Sri Lanka are treated as one biogeographical unit (Gunawardene et al. 2007) and hence the present discovery of this species from the Western Ghats is not a surprise.

Acknowledgements - We thank the Tamil Nadu State Forest Department for permission to explore the study area. AEDD thanks the Department of Science and Technology (DST), New Delhi, for financial assistance and the Principal, Scott Christian College, for facilities.

\section{REFERENCES}

Bruehl, P. (1931): A census of Indian mosses with analytical keys to the genera. - Rec. Bot. Surv. India 13(1): 1-135.

Chopra, R. S. (1975): Taxonomy of Indian mosses. - CSIR, New Delhi, India, 631 pp.

Gangulee, H. C. (1969-1980): Mosses of Eastern India and adjacent regions. 1-3 (Fasc. 1-8). Calcutta, India, $2142 \mathrm{pp}$.

Gunawardene, N. R., Daniels, A. E. D., Gunatilleke, I. A. U. N., Gunatilleke, C. V. S., Karunakaran, P. V., Nayak, K. G., Prasad, S., Puyravaud, P., Ramesh, B. R., Subramanian, K. A. and Vasanthy, G. (2007): A brief overview of the Western Ghats-Sri Lanka biodiversity hotspot. - Curr. Sci. 93: 1567-1572.

Lal, J. (2005): A checklist of Indian mosses. - Bishen Singh Mahendra Pal Singh, Dehra Dun, India, $164 \mathrm{pp}$.

Mohamed, H. and Robinson, H. E. (1991): A taxonomic revision of the moss families Hookeriaceae and Hypopterygiaceae in Malaya. - Smiths. Contr. Bot. 80: 1-44. https:// doi.org/10.5479/si.0081024x.80

Schwarz, U. (2013): An updated checklist of bryophytes of Karnataka. - Arch. Bryol. 181: $1-42$. 